\title{
PENGARUH MODEL PEMBELAJARAN INKUIRI TERBIMBING MENGGUNAKAN MEDIA SEDERHANA TERHADAP HASIL BELAJAR IPA FISIKA PADA SISWA KELAS VIII SMP NEGERI 3 PALU
}

\author{
Filda Mohammad Said, H. Muhammad Ali dan I Komang Werdhiana \\ Jurusan Pendidikan MIPA \\ Fakultas Keguruan dan IImu Pendidikan Universitas Tadulako Palu
}

\begin{abstract}
Abstrak - Model pembelajaran inkuiri terbimbing merupakan pembelajaran yang melibatkan siswa dalam menentukan suatu konsep atau materi pelajaran yang sedang dipelajari. Keterlibatan siswa dalam proses pembelajaran tersebut dapat berupa mengajukan berbagai pertanyaan, menghimpun informasi, dan melakukan penyelidikan. Pembelajaran langsung (DI) merupakan suatu model pembelajaran yang terdiri dari penjelasan guru mengenai konsep atau keterampilan baru terhadap siswa. Penelitian ini dilakukan dengan tujuan mengetahui pengaruh model pembelajaran inkuiri terbimbing menggunakan media sederhana terhadap hasil belajar IPA fisika pada siswa SMP Negeri 3 Palu. Jenis penelitian ini merupakan eksperimen kuasi dengan desain the non-equivalent pretest-posttest. Populasi penelitian adalah siswa kelas VIII SMP Negeri 3 Palu. Teknik Sampling yang digunakan dalam penelitian ini adalah purposive sampling dengan sampel penelitian adalah kelas VIII A sebagai kelompok eksperimen dan kelas VIII B sebagai kelompok kontrol. Instrumen hasil belajar IPA fisika berupa tes pilihan ganda yang telah divalidasi melalui validitas konstruksi. Hasil uji t dua pihak dengan $\mathrm{dk}=60 \mathrm{dan}$ taraf signifikansi $\alpha=0,05$ diperoleh nilai thitung $=3,92$ dan nilai ini lebih besar dari $t_{\text {tabel }}=2,00$. Hal ini berarti, nilai thitung berada di luar daerah penerimaan $\mathrm{H}_{0}$. Dengan demikian $\mathrm{H}_{0}$ ditolak dan $\mathrm{H}_{1}$ diterima, dan dapat disimpulkan bahwa ada pengaruh model pembelajaran Inkuiri terbimbing menggunakan media sederhana terhadap hasil belajar IPA fisika pada siswa SMP Negeri 3 Palu.
\end{abstract}

Kata Kunci : inkuiri terbimbing, media sederhana, pembelajaran langsung, hasil belajar

\section{PENDAHULUAN}

Hasil belajar siswa pada hakikatnya adalah perubahan tingkah laku yang diperoleh siswa setelah mengalami aktivitas belajar [1]. Hasil belajar yang diperoleh sangat bergantung kepada cara-cara belajar yang digunakan. Pada tingkat berpikir inilah dapat diharapkan bahwa dengan mempergunakan cara belajar yang efisien akan mempertinggi hasil belajar yang memuaskan [2].

Salah satu upaya untuk mengatasi masalah pemahaman siswa yang mengakibatkankan rendahnya hasil belajar siswa adalah model pembelajaran yang melatih siswa lebih aktif yakni dengan menggunakan model pembelajaran inkuiri terbimbing menggunakan media sederhana, dalam hal ini model pembelajaran inkuiri terbimbing menggunakan media sederhana yang diharapkan mampu memacu aktivitas dan kreativitas siswa.

Model pembelajaran inkuiri terbimbing adalah siswa bekerja untuk menemukan jawaban terhadap masalah yang dikemukakan oleh guru dibawah bimbingan yang intensif dari guru. Guru datang ke kelas dengan membawa masalah untuk dipecahkan oleh siswa, kemudian mereka dibimbing untuk menemukan cara terbaik dalam memecahkan masalah tersebut [3]. Sedangkan media pembelajaran sederhana adalah media pembelajaran yang tidak berbasis teknologi modern dan dapat dibuat sendiri dengan relatif mudah karena menggunakan bahan yang ada di lingkungan dan tidak memerlukan biaya yang mahal [4].

Hasil penelitian telah menunjukan bahwa model pembelajaran inkuiri terbimbing dengan metode eksperimen memberikan pengaruh yang lebih baik, yaitu membuat siswa lebih aktif dalam belajar dan meningkatkan hasil belajar fisika siswa. Penggunaan metode eksperimen pada model pembelajaran inkuiri ini sangat mendukung siswa dalam menemukan konsep-konsep pada materi yang diajarkan [5].

Menurut Setiowati [6], hasil prestasi belajar siswa yang mencakup aspek pengetahuan, sikap, dan keterampilan dapat dinyatakan bahwa penerapan model pembelajaran inkuiri terbimbing dapat meningkatkan prestasi belajar siswa. Penerapan model pembelajaran inkuiri terbimbing memberikan kesempatan kepada siswa untuk lebih aktif dalam kegiatan pembelajaran guna mengembangkan konsep yang telah dimiliki sebelumnya sehingga diperoleh pembelajaran yang bermakna.

Bedasarkan uraian di atas banyak yang melakukan penelitian tentang model pembelajaran inkuiri terbimbing. Penelitian terdahulu juga pernah dilakukan oleh Pratiwi [7]. Hasil penelitian menjadikan siswa lebih aktif dalam memecahkan masalah dan terlibat langsung dalam proses pembelajaran dimana informasi dan pengetahuan mereka temukan secara mandiri dalam kelompok, saling berinteraksi bukan hanya dengan guru tetapi juga dengan teman mereka. 
Hal ini karena pada pembelajaran inkuiri terbimbing siswa dapat mengembangkan cara berpikir ilmiah yang menempatkan siswa sebagai pembelajar dalam memecahkan permasalahan penyelidikan sehingga dapat memahami konsepkonsep sains.

Pada penelitian yang akan dilakukan kali ini model pembelajaran tersebut akan dipadukan dengan penggunaan media pembelajaran sederhana. Media pembelajaran sederhana ini sangat mendukung siswa dalam menemukan konsep-konsep pada materi yang diajarkan dan peran guru sebagai pembimbing.

Adapun sintaks model pembelajaran inkuiri terbimbing menggunakan media sederhana yaitu orientasi masalah eksperimen, berhipotesis secara eksperimen, menguji hipotesis, presentasi data hasil eksperimen, umpan balik dan penarikan kesimpulan.

Tujuan dari penelitian ini adalah untuk mengetahui ada tidaknya pengaruh model pembelajaran inkuiri terbimbing menggunakan media sederhana terhadap hasil belajar IPA fisika pada siswa kelas VIII SMP Negeri 3 Palu. dam memperoleh pengetahuan yang bersifat

Adapun manfaat penelitian ini adalah memberikan kesempatan kepada siswa untuk berpartisipasi aktif dalam proses pembelajaran dan dapat meningkatkan semangat dalam mengikuti pelajaran. Sedangkan bagi guru, dapat dijadikan sebagai bahan pertimbangan dan bahan masukan tentang model pembelajaran yang dapat mengaktifkan siswa dalam proses pembelajaran.

\section{METODOLOGI PENELITIAN}

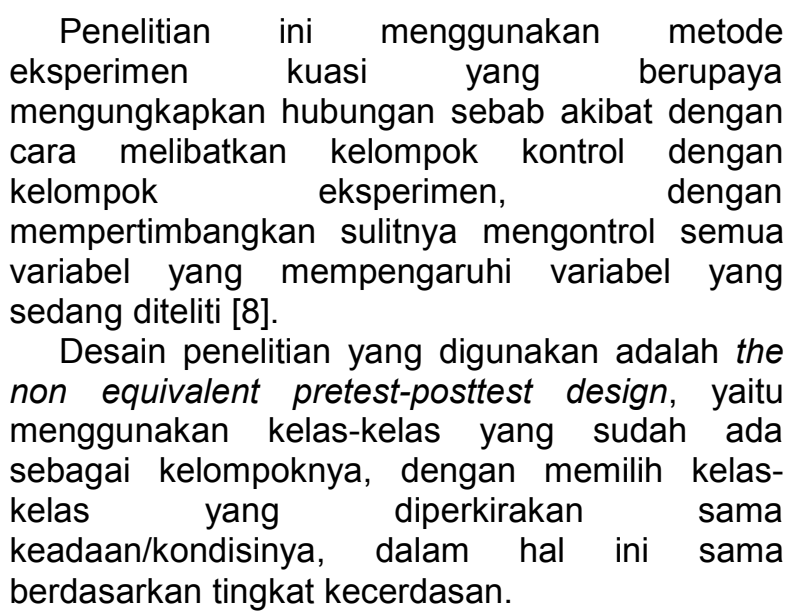

TABEL 1 DESAIN PENELITIAN

\begin{tabular}{cccc}
\hline Kelompok & Pretest & Perlakuan & Posttest \\
\hline Eksperimen & $\mathrm{O}$ & $\mathrm{X}$ & $\mathrm{O}$ \\
\hline Kontrol & $\mathrm{O}$ & - & $\mathrm{O}$ \\
\hline
\end{tabular}

Keterangan:

X :Model pembelajaran inkuiri terbimbing menggunakan media sederhana

- $\quad$ : Pembelajaran konvensional (Direct Intruction)

O : Pretest dan Posttest

Populasi penelitian ini adalah seluruh siswasiswi kelas VIII SMP Negeri 3 Palu Tahun Ajaran 2017/2018.

Sampel dari penelitian ini adalah siswa-siswi kelas VIII SMP Negeri 3 Palu yaitu kelas VIII A sebagai kelas Eksperimen dan kelas VIII B sebagai kelas kontrol. Jumlah siswa kelas eksperimen yaitu 32 orang dan kelas kontrol sebanyak 30 orang.

Teknik pengambilan sampel yang digunakan yaitu teknik purposive sampling yaitu penentuan sampel dengan pertimbangan tertentu. Guru di sekolah mengambil kelas dengan pertimbangan kemampuan pada tiap kedua kelas di anggap sama. Dari pengambilan sampel maka terpilih kelas VIII A sebagai kelas eksperimen dan kelas VIII B sebagai kelas kontrol, kedua kelas yang dipilih merupakan kelas yang dianggap homogen secara akademik.

Instrumen yang digunakan yaitu instrumen tes dan instrumen perlakuan. Instrumen tes berupa tes objektif (pilihan ganda) digunakan untuk mengevaluasi perubahan hasil belajar siswa. Instrumen perlakuan berupa perangkat pembelajaran yang terdiri dari Rencana Pelaksanaan Pembelajaran (RPP), LKS, bahan ajar, serta media pembelajaran sederhana.

Data yang diperoleh dari penelitian ini selanjutnya diolah dengan menggunakan uji statistik berupa uji normalitas (chi kuadrat), uji homogenitas (fisher), dan uji hipotesis (uji t-dua pihak).

\section{HASIL DAN PENELITIAN}

\section{Hasil penelitian}

1. Deskripsi Hasil Pretest

Skor rata-rata pretest kelas eksperimen sebesar 8,06 dengan standar deviasi sebesar 3,20 . Sedangkan untuk kelas kontrol, skor rataratanya sebesar 8,03 dan standar deviasi sebesar 2,91 . Selanjutnya pada post-test, skor rata-rata 
Pengaruh Model Pembelajaran Inkuiri Terbimbing Menggunakan Media Sederhana Terhadap Hasil Belajar IPA Fisika Pada Siswa Kelas VIII SMP Negeri 3 Palu (Filda Mohammad Said)

kelas eksperimen sebesar 20,00 dengan standar deviasi 3,21 dan untuk kelas kontrol skor rataratanya sebesar 16,90 dengan standar deviasi sebesar 3,11

TABEL 2 DESKRIPSI SKOR TES HASIL BELAJAR FISIKA SISWA UNTUK KELAS EKSPERIMEN DAN KELAS KONTROL.

\begin{tabular}{lcccc}
\hline \multirow{2}{*}{ Uraian } & \multicolumn{2}{c}{ Pretest } & \multicolumn{2}{c}{ Posttest } \\
\cline { 2 - 5 } & Eksperimen & Kontrol & Eksperimen & Kontrol \\
\hline Sampel $(\mathrm{n})$ & 32 & 30 & 32 & 30 \\
\hline Nilai maksimum & 13 & 13 & 25 & 22 \\
\hline Nilai minimum & 2 & 2 & 20,00 & 11 \\
\hline Skor rata-rata & 8,06 & 8,03 & 3,21 & 3,11 \\
\hline Standar deviasi & 3,20 & 2,91 & & 30 \\
\hline
\end{tabular}

2. Uji Normalitas

Uji normalitas data digunakan untuk mengetahui apakah populasi data berdistribusi

normal. Setelah dilakukan pengolahan data. Hasil uji normalitas dapat dilihat pada tabel 3

TABEL 3 HASIL UJI NORMALITAS PRETEST DAN POSTTEST PADA KELAS EKSPERIMEN DAN KELAS KONTROL

\begin{tabular}{lcccc}
\hline \multirow{2}{*}{ Uraian } & \multicolumn{2}{c}{ Kelas Kontrol } & \multicolumn{2}{c}{ Kelas Eksperimen } \\
\cline { 2 - 5 } & Pretest & Posttest & PreTest & Posttest \\
\hline Jumlah Siswa & 30 & 30 & 32 & 32 \\
$\chi^{2}$ hitung & & & 4,58 & 4,76 \\
$\chi^{2}$ tabel & 4,27 & 4,73 & 7.81 & 7.81 \\
\hline
\end{tabular}

Hasil uji normalitas kedua kelas pada tabel 3 menunjukan bahwa nilai $\mathrm{X}^{2}$ hitung kelas eksperimen maupun kelas kontrol lebih kecil dari pada nilai $\mathrm{X}^{2}$ tabel. Artinya, hal ini menunjukkan sampel dari kelas eksperimen dan kelas kontrol berasal dari populasi yang berdistribusi normal.
3. Uji Homogenitas

Setelah dilakukan pengolahan data, tampilan hasil analisis dapat dilihat pada Tabel 4.

TABEL 4 HOMEGENITAS DUA VARIANS PRETEST DAN POSTEST KELAS EKSPERIMEN DAN KELAS KONTROL

\begin{tabular}{lcccc}
\hline \multirow{2}{*}{ Uraian } & \multicolumn{3}{c}{ Pretest } & \multicolumn{2}{c}{ Posttest } \\
\cline { 2 - 5 } & Eksperimen & Kontrol & Eksperimen & Kontrol \\
\hline Nilai Variansi & 10,25 & 8,64 & 10,32 & 9,70 \\
\hline Variansi Hitung & & 0,83 & & 1,06 \\
\hline $\begin{array}{l}\text { Nilai F tabel }(\alpha \\
=0,05)\end{array}$ & 2,34 & \multirow{2}{*}{2,41} \\
\hline Keputusan & \multicolumn{3}{c}{ Homogen } & \multicolumn{2}{c}{} \\
\hline
\end{tabular}

Berdasarkan hasil uji homogenitas pada Tabel 4 dengan taraf signifikan $(\alpha=0,05)$, menunjukan dimana $F_{\text {hitung }}<F_{\text {tabel }}$ maka data tersebut memiliki varians yang sama (homogen).
4. Uji Hipotesis

Pengujian hipotesis menggunakan parametrik, data hasil pengujian statistik dapat dilihat pada tabel 5 
Pengaruh Model Pembelajaran Inkuiri Terbimbing Menggunakan Media Sederhana Terhadap Hasil Belajar IPA Fisika Pada Siswa Kelas VIII SMP Negeri 3 Palu

(Filda Mohammad Said)

TABEL 5 UJI SIGNIFIKAN (DUA PIHAK) PADA KELAS EKSPERIMEN DAN KELAS KONTROL

\begin{tabular}{cccc} 
& thitung & tabel $(\alpha=0,05)$ & Keputusan \\
\hline Pretest & 0,04 & 2,00 & $\mathrm{H}_{0}$ diterima \\
\hline Posttest & 3,92 & 2,00 & $\mathrm{H}_{1}$ diterima \\
\hline
\end{tabular}

Berdasarkan hasil uji hipotesis pada tabel $5 \mathrm{H}_{1}$ diterima jika $t_{\text {hitung }}>t_{\text {tabel }}$ pada taraf nyata $\alpha=$ 0,05 dan $d k=60$ dan untuk harga t lainnya ditolak. Dari daftar distribusi $\mathrm{t}$ diperoleh harga $t_{\text {tabel }}=2,00$ sedangkan $t_{\text {hitung }}=3,92$. Hal ini berarti $H_{0}$ ditolak sedangkan $H_{1}$ diterima. Dengan demikian, dapat disimpulkan bahwa ada pengaruh hasil belajar fisika antara kelas yang menggunakan model pembelajaran inkuiri terbimbing menggunakan media sederhana dengan kelas yang menggunakan model pembelajaran direct instruction [9].

\section{Pembahasan}

Hasil perolehan skor rata-rata posttest menunjukan bahwa terdapat perbedaan hasil belajar yang signifikan dari siswa yang mengggunakan model pembelajaran inkuiri terbimbing menggunakan media sederhana dengan siswa yang menggunakan model pembelajaran direct intruction (pembelajaran lansung). Model pembelajaran inkuiri terbimbing menggunakan media sederhana berpengaruh positif terhadap hasil belajar siswa.

Hal ini dikarenakan model pembelajaran inkuiri terbimbing menggunakan media sederhana dapat membuat siswa terlibat aktif dalam proses pembelajaran dengan adanya bimbingan dari guru. Pada model pembelajaran inkuiri terbimbing siswa mampu berpikir secara maksimal seperti dapat mengemukakan hipotesis, menajukan pertanyaan, menghimpun informasi dan membuktikan konsep secara nyata atau materi pembelajaran yang sedang dipelajari melalui eksperimen.

Pada penggunaan media sederhana, siswa dapat melihat secara langsung tentang objek yang sedang dipelajari tanpa harus beranganangan dan dapat mengembangkan konsep yang dipelajari dengan teman kelompoknya serta dapat meningkatkan hasil belajar IPA fisika dan minat siswa untuk belajar IPA fisika.

Dari penelitian ini memperlihatkan adanya peningkatan hasil belajar siswa. Penelitian sebelumnya juga menunjukkan bahwa model pembelajaran inkuiri terbimbing dapat lebih meningkatkan kemampuan berpikir kritis peserta didik. Hal tersebut dapat terjadi karena model ini melibatkan peserta didik aktif baik secara fisik maupun mental dalam belajarnya. Peserta didik diajak berpikir mengenali masalah, menyelidiki untuk mencari jawaban terhadap masalah yang dihadapi sampai pada penyusunan kesimpulan. Hal tersebut membuat peserta didik terlatih untuk berpikir kritis [10].

Kelebihan dalam proses pembelajaran yaitu siswa dapat menemukan sendiri konsep yang dipelajari dengan melakukan eksperimen yang menggunakan media sederhana dan dengan melakukan ekperimen juga siswa tidak beranganangan tentang materi yang dipelajari, peran guru hanya sebagai pembimbing. Kekurangan dalam proses pembelajaran adalah emanfaatan waktu belajar di kelas dalam pelaksanaan praktikum yang kurang diefektifkan juga menjadi kendala dalam proses pembelajaran. Berdasarkan penjelasan di atas dan penelitian yang dilakukan, terbukti bahwa terdapat perbedaan hasil belajar antara siswa yang mengikuti model pembelajaran inkuiri terbimbing menggunakan media sederhana dengan siswa yang mengikuti model pembelajaran direct intruction (pembelajaran langsung).

\section{KESIMPULAN DAN SARAN}

\section{Kesimpulan}

Berdasarkan hasil analisa data penelitian, maka disimpukan terdapat pengaruh model pembelajaran inkuiri terbimbing menggunakan media sederhana terhadap hasil belajar IPA fisika pada siswa kelas VIII SMP Negeri 3 Palu. Hal ini ditunjukkan hasil uji hipotesis dengan thitung sebesar 3,92 dan nilai tabel pada taraf signifikan ( $\alpha$ $=0,05)$ sebesar 2,00 maka hipotesis nol $\left(\mathrm{H}_{0}\right)$ di tolak dan hipotesis satu $\left(\mathrm{H}_{1}\right)$ diterima.

\section{Saran}

Dari hasil penelitian yang telah dilakukan penulis mengajukan beberapa saran sebagai bahan perbaikan dimasa akan datang:

1. Untuk penelitian selanjutnya, jika ingin menggunakan model pembelajaran inkuiri terbimbing menggunakan media sederhana dapat dilakukan perbaikan pada perencanaan waktu pembelajaran, yaitu dengan mengurangi waktu praktikum. Agar pembelajaran berjalan 
Pengaruh Model Pembelajaran Inkuiri Terbimbing Menggunakan Media Sederhana Terhadap Hasil Belajar IPA Fisika Pada Siswa Kelas VIII SMP Negeri 3 Palu (Filda Mohammad Said)

sesuai perencanaan serta tidak melebihi waktu yang ditentukan.

2. Untuk peneliti selanjutnya, jika ingin melakukan penelitian yang sama dengan menggunakan model pembelajaran inkuiri terbimbing menggunakan media sederhana, disarankan dengan materi yang berbeda dan membandingkannya dengan model lainnya.

\section{DAFTAR PUSTAKA}

[1] N. Sudjana and Ibrahim, Penelitian dan Penilaian Pendidikan. Bandung: Sinar Baru Algensindo, 2012.

[2] O. Hamalik, Proses Belajar Mengajar. Bandung: Bumi Aksara, 2008.

[3] K. Anam, Pembelajaran Berbasia Inkuiri. Yogyakarta: Pustaka Belajar, 2015.

[4] N. Kertiasa, Pemanfaatan Alat Sederhana Sebagai Sumber Belajar, 1994. diunduh pada tanggal 14 Mei 2013.

[5] R. Wahyuni, "Pengaruh Model Pembelajaran Inkuiri Terbimbing dengan Metode Eksperimen Terhadap Hasil Belajar Fisika Siswa Kelas XI IPA SMAN 2 Mataram Tahun
Pelajaran 2016/2017," Jurnal Pendidikan Fisika dan Teknologi. Volume II, No 4, 2016.

[6] H. Setiowati, "Penerapan Model Pembelajaran Inkuiri Terbimbing (Guided Inquiry) Dilengkapi LKS untuk Meningkatkan Aktivitas dan Prestasi Belajar Siswa Pada Materi Pokok Kelarutan dan Hasil Kali Kelarutan Kelas XI MIA SMA Negeri 1 Banyudono Tahun Pelajaran 2014/2015," Jurnal Pendidikan Kimia (JPK). Vol. 4 No. 4. Hal. 54-60, 2015.

[7] N. Pratiwi, "Pengaruh Model Pembelajaran Inkuiri Terbimbing Terhadap Hasil Belajar IPA Fisika Siswa Kelas VII SMP Negeri 1 Dolo," Jurnal Pendidikan Fisika Tadulako. Vol. 1, No. 4, 2014.

[8] Sugiyono, Metode Penelitian Pendidikan (Pendekatan Kuantitatif, Kualitatif dan R\&D). Bandung: CV. Alfabeta, 2012.

[9] Sudjana, Metode Statistika. Bandung: Cv Tarsito, 2015.

[10] L. Nurmayani, "Pengaruh Model Pembelajaran Inkuiri Terbimbing Terhadap Kemampuan Berpikir Kritis Peserta Didik," Jurnal Pendidikan Fisika dan Teknologi. Vol. 4, No. 1, 2018. 